\title{
Prehrambene specifičnosti proteina i masti u kobiljem mlijeku u odnosu na
} humano i kravlje mlijeko

\author{
A. Končurat*, L. Kozačinski, N. Bilandžić, T. Sukalić i Ž. Cvetnić
}

\section{Sažetak}

Zadnjih se desetljeća kobilje mlijeko istražuje kao funkcionalna i ljekovita hrana. Sastav kobiljeg, humanog i kravljeg mlijeka znatno se razlikuje, a varira i o genetskim, fiziološkim i prehrambenim čimbenicima, kao i o uvjetima okoliša. Uspoređujući ga s humanim i kravljim mlijekom, kobilje mlijeko ima nižu energetsku vrijednost i niže vrijednosti masti. Sadržaj proteina sirutke i kazeina u kobiljem mlijeku sličan je onom u humanom za prehranu ljudi i čini ga pogodnijim od kravljega. Kobilje i humano mlijeko formiraju precipitat koji je lakše probavljiv od koaguluma kravljeg mlijeka. Vanjska membrana masnih globula, kao i raspodjela di- i tri- glicerida iz kobiljeg i humanog mlijeka su slične. Postotak nezasićenih masnih kiselina $u$ kobiljem i humanom mlijeku veći je nego u kravljem mlijeku, a najveći dio otpada na polinezasićene masne kiseline sa srednjim i većim brojem ugljikovih atoma. Kobilje mlijeko zauzima sve više prostora $\mathrm{u}$ nutricionizmu zbog svojih specifičnih kemijskih i nutritivnih karakteristika,

Ključne riječi: kobilje mlijeko, proteini, masti, usporedba

\section{Uvod}

Kobilje mlijeko je najvažniji i jedini izvor hranjivih tvari za ždrijebad prvih nekoliko mjeseci života, a osim toga je i izuzetno cijenjena namirnica koju su tradicionalno koristili nomadskih narodi u predjelima središnje Azije, gdje njegova primjena seže daleko u povijest.

Osim konzumiranja u sirovom obliku, kobilje mlijeko se koristi i kao sirovina za proizvodnju kumisa, napitka od fermentiranog kobiljeg mlijeka. Zbog proizvodnje mlijeka uzgoj je konja najrašireniji je u zemljama središnje Azije (Kazahstan, Uzbekistan, Kirgistan,

Dr. sc. Ana KONČURAT*, dr. med. vet., znanstvena suradnica, (dopisni autor, e-mail: koncurat.vzk@ veinst.hr), Hrvatski veterinarski institut Zagreb - Veterinarski zavod Križevci, Hrvatska; dr. sc. Lidija KOZAČINSKI, dr. med. vet., redovita profesorica, Veterinarski fakultet Sveučilišta u Zagrebu, Hrvatska; dr. sc. Nina BILANDŽIĆ, dipl. ing. biotehnol., znanstvena savjetnica u trajnom zvanju, Hrvatski veterinarski institut Zagreb, Hrvatska; dr. sc. Tomislav SUKALIĆ, dr. med. vet., poslijedoktorand, dr. sc. Željko CVETNIĆ, dr. med. vet., akademik, Hrvatski veterinarski institut Zagreb - Veterinarski zavod Križevci, Hrvatska 
Tadžikistan, Turkmenistan), području Kavkaza i u nekim dijelovima Rusije blizu Kazahstana, Mongolije, Sibira, Sjeverne Kine i Tibeta. Nešto manje količine kobiljeg mlijeka se proizvode $\mathrm{u}$ istočnoj (Ukrajina, Bjelorusija) i srednjoj Europi (Mađarska, Austrija, Bugarska i Njemačka) (Sheng i Fang, 2009., Brezovečki i sur., 2014.). Upravo su na tom području i nastali prvi radovi kojima se ukazuje na dobrobit konzumiranja kobiljeg mlijeka. U ostalim je dijelovima svijeta značenje proizvodnje kobiljeg mlijeka, u usporedbi s proizvodnjom kravljeg, ovčjeg i kozjeg, neznatno. Ipak, zadnjih desetljeća raste interes za konzumacijom kobiljeg mlijeka i u zemljama Europske unije, gdje se provode istraživanja kobiljeg mlijeka kao funkcionalne i ljekovite namirnice. Najviše se konzumira u Francuskoj, Italiji, Mađarskoj, Njemačkoj i Nizozemskoj. U kobila se uzgojna selekcija u smislu poboljšavanja i optimizacije hereditarnih svojstva vezanih uz laktaciju ne provodi, a organizirana proizvodnja kobiljeg mlijeka je, $\mathrm{u}$ odnosu na proizvodnju kravljeg, skupa.

S nutritivnog gledišta, kobilje mlijeko ima zanimljiv sastav te se provode istraživanja kojima se ukazuje na mogućnost korištenja kobiljeg mlijeka kao zamjene za kravlje, a u djece koja pate od alergija (Businco i sur., 2000.) i zamjene za majčino mlijeko u prerano rođene djece (Caroprese i sur., 2007.). Dosadašnja istraživanja dokazuju prihvatljiv sastav kobiljeg mlijeka u prehrani starijih osoba, rekonvalescenata i djece (Uniacke-Lowe i sur., 2010.) i preporučuju kobilje mlijeko kao funkcionalnu hranu, odnosno hranu koja daje određenu zdravstvenu dobrobit (Ellinger i sur., 2002.).

Prema sastavu, kobilje se mlijeko nalazi između kravljeg i humanog (Marconi i Panfili, 1998.), a nalikuje magarećem mlijeku (Salimei i sur., 2004.), koje zbog hranjivih i funkcionalnih sastojaka pobuđuje interes znanstvenika
(Ivanković i sur., 2009.). I svježe i fermentirano kobilje mlijeko sadrži povoljan sastav imunoglobulina pa se tradicionalno koristi u sprječavanju i liječenju dugih i teških bolesti (tuberkuloza), kod metaboličkih, gastrointestinalnih i problema s jetrom, nakon kirurških zahvata, u liječenju bronhitisa, kod alergija, a smatra se i da podiže otpornost organizma nakon kemoterapija i zračenja. Kobilje mlijeko se koristi i kod dermatoloških bolesti (neurodermitis, psorijaza) te $\mathrm{u}$ izradi kozmetičkih pripravaka (Ernoić, 1998.). Zbog svojih specifičnih kemijskih i nutritivnih karakteristika, kobilje mlijeko zauzima sve više prostora $u$ nutricionizmu.

U ovom će radu biti prikazan sastav kobiljeg mlijeka u usporedbi s humanim i kravljim mlijekom, uzimajući u obzir najvažnije proteinske i frakcije mliječne masti te sadržaj masnih kiselina. Promatran je sadržaj kazeina, proteina sirutke, sastav lipida i masnih kiselina, s naglaskom na njihove količine i omjere. Kobilje mlijeko ima strukturalne i funkcionalne osobitosti, koje ga čine lako probavljivim i pogodnim za ljudsku prehranu.

\section{Anatomija vimena i sastav kobiljeg mlijeka}

Vime je kobile visoko postavljeno $\mathrm{u}$ ingvinalnoj regiji i sastoji se od dvije simetrične polovine, koje se dodiruju u medijalnoj ravnini, a odvaja ih intermamarni žlijeb. I lijeva i desna polovina vimena sadrže po dvije mliječne žlijezde - prednju i stražnju četvrt. Kao i kod ostalih egzokrinih žlijezda, parenhim mliječne žlijezde sadrži sekretorne stanice i odvodne kanale. Sekretorne stanice čini jednostavan epitel koji oblikuje brojne kruškolike alveole, u čiji se lumen izlučuje mlijeko. Žlijezdano tkivni parenhim povezan je intersticijalnim vezivnim tkivom, s 
krvnim žilama i živcima, koji osiguravaju dobru inerviranost i prokrvljenost. Grupe alveola formiraju lobule karakteristične za tkivo mliječne žlijezde. Svaku alveolu okružuje mreža mioepitelnih stanica koje se kontrahiraju i potiskuju mlijeko iz alveola u kanale. Veći kanali konvergiraju do mliječnih cisterni u kojima se sakuplja i zadržava mlijeko. Iz cisterni se spuštaju sisni kanali. Za razliku od kravljeg, vime kobile ima dvije sise, a kroz svaku se spuštaju po dva sisna kanala (Starbuck, 2006.).

U svih sisavaca mlijeko je temeljni izvor hrane za mladunčad kojom se osigurava rast i razvoj, a ima i veliku imunološku ulogu. Ždrjebad u prva dva mjeseca života znatno raste, a mlijeko je u toj početnoj i kritičnoj fazi, pogotovo tijekom prvog mjeseca, jedini izvor svih hranjivih tvari (Martin i sur., 1992., Martuzzi i sur., 1997.).

Kao i u ostalih vrsta i mlijeko kobila se najvećim dijelom sastoji od vode; osim vode $u$ mlijeku je i suha tvar koju čine brojni različiti sastojci, a glavne komponente su: masti, bjelančevine i ugljikohidrati. S prehrambenog su gledišta važni još i minerali i vitamini (Tratnik, 1998.). Koncentracije glavnih sastojaka variraju ovisno o vrsti, a sama sekrecija mlijeka fiziološki je diktirana i strukturalno povezana s prehrambenim potrebama podmlatka.

Uočene su sličnosti u sastavu mlijeka pripadnika istog taksonomskog reda, primjerice, u mlijeku ekvida. Ždrijebe $\mathrm{u}$ periodu sisanja ima na raspolaganju dovoljnu količinu mlijeka, koja se tijekom laktacije mijenja, a povećava se tijekom prvih tjedana života (Summer i sur. 2000.).

Sastavi kobiljeg, humanog i kravljeg mlijeka znatno se razlikuje $\mathrm{u}$ prehrambenim vrijednostima. U usporedbi s kravljim, kobilje mlijeko sadrži manje mliječne masti ibjelančevina, a ima više laktoze po čemu je slično humanom i magarećem mlijeku (Salimei i sur., 2004.). Kobilje mlijeko pripada albuminskom tipu mlijeka i ima povoljan sastav imunoglobulina. U odnosu na kravlje, kobilje mlijeko sadrži manje suhe i anorganskih tvari.

S obzirom na sastav i frakcije proteina, kobilje je mlijeko sličnije humanom $u$ odnosu na mlijeko preživača (Potočnik i sur., 2011.).

U svih životinjskih vrsta na sastav mlijeka najviše utječe stadij laktacije, jer su najznačajnije razlike između kolostruma i mlijeka nakon kolostruma (Casey, 1989.). Ubrzo nakon partusa stvara se kolostrum koji je bogat suhom tvari, proteinima, mastima, vitaminima i mineralima, a siromašniji laktozom od mlijeka. Najznačajnija biološka uloga kolostruma je prisustvo imunoglobulina i visoka razina enzima (Uniacke-Lowe, 2011.). Utječe li na sastav kobiljeg mlijeka pasminska pripadnost još nije do kraja razjašnjeno, jer su neki autori (Csapo-

Tabela 1. Prikaz sastava različitih vrsta mlijeka s obzirom na količinu mliječne masti, bjelančevina i laktoze

\begin{tabular}{|c|c|c|c|c|}
\hline Vrsta & Mliječna mast & Bjelančevine & Laktoza & Izvor \\
\hline Kravlje & 36,1 & 32,5 & 48,8 & Malacarne i sur. 2002. ${ }^{\text {a }}$ \\
\hline Kozje & 38,0 & 35,0 & 41,0 & Uniacke-Lowe i sur., 2010. ${ }^{\text {b }}$ \\
\hline Ovčje & 68,2 & 55,9 & 48,8 & \\
\hline Ženino & 36,4 & 14,2 & 67,0 & Malacarne i sur. 2002. ${ }^{\text {a }}$ \\
\hline Kobilje & 12,1 & 21,4 & 63,7 & \\
\hline
\end{tabular}

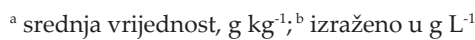


Kiss i sur., 1995.) mišljenja da pasmina ne utječe na koncentraciju bjelančevina, pepela, makro i mikroelemenata $u$ kobiljem mlijeku, dok drugi (Formaggioni i sur., 2003., Pieszka i sur., 2011.) naglašavaju značajne pasminske razlike u sadržaju bjelančevina. Kvalitativne razlike između mlijeka vrsta navedenih u Tabeli 1. nesumnjivo su izrazite, a bitno je napomenuti i strukturalne razlike i to najviše $u$ proteinskim frakcijama i sastavu masti.

\section{Proteini sirutke i kazeini u kobiljem mlijeku}

Od ukupnih dušičnih tvari u mlijeku se nalazi oko $95 \%$ proteina i 5 $\%$ neproteinske dušične tvari. Proteini mlijeka pripadaju dvjema kategorijama, a razlikuju se prema topivosti pri $\mathrm{pH} 4,6$ i $20^{\circ} \mathrm{C}$, pod čijim uvjetima jedna skupina proteina precipitira, a čine ju kazeini. Proteini koji se pod navedenim uvjetima ne istalože, već ostanu otopljeni, nazivaju se proteinima sirutke (Fox, 2001.). U kravljem se mlijeku nalazi približno 80 $\%$ kazeina što ga definira kazeinskim mlijekom. Proteini sirutke, za razliku od kazeina oblikuju mekši, rastresiti gruš i lakše su probavljivi (Tratnik, 1998.). Za razliku od kravljeg, kobilje mlijeko sadrži manje kazeina (50-65 \%) i više proteina sirutke te se ubraja $\mathrm{u}$ albuminsko mlijeko (Brezovečki i sur., 2014.). Frakcija proteina sirutke $\mathrm{u}$ kobiljem mlijeku čini približno $40 \%$, nešto ih je više u humanom mlijeku (50 \%), dok je ta frakcija u kravljem mlijeku znatno niža (20\%). Proteini kravljeg mlijeka i mlijeka ostalih preživača imaju sasvim drugačije osobine, a najznačajnija je kiseloenzimatska koagulacija. Cjelokupni proteinski sastav kobiljeg mlijeka dosta je sličan onome u humanom mlijeku, odnosno komparabilni su i proteini sirutke u cijelosti, kao i koncentracija neproteinskih dušičnih tvari. S ovog je aspekta kobilje mlijeko sličnije humanom mlijeku i može se definirati kao tipično albuminsko mlijeko. Zbog velike količine proteina sirutke, ima i veću količinu esencijalnih aminokiselina pa je time kobilje mlijeko pogodnije od kravljeg za ljudsku prehranu.

Omjer kazeina i proteina sirutke $u$ kravljem mlijeku iznosi 4,7:1; u humanom 0,4:1; a u kobiljem 1,1:1 (Uniacke-Lowe i sur., 2010.). Raspodjela pojedinih proteina sirutke fiziološki je specifična za svaku vrstu, a koncentracija i preraspodjela pojednih proteina i enzima prisutnih $\mathrm{u}$ sirutki prikazana je u Tabeli 2. U kobiljem mlijeku većinu proteina sirutke čine $\beta$-laktoglobulin, $\alpha$-laktalbumin, imunoglobulini, albumini krvnog seruma, laktoferin i lizozim, slično kao i u kravljem mlijeku. Međutim, relativne vrijednosti pojedinih proteina znatno se razlikuju između ovih vrsta. Humano mlijeko siromašno je na $\beta$-laktoglobulinu, dok je isti protein prisutan $\mathrm{u}$ znatnim količinama i u kravljem i u kobiljem mlijeku. Taj je protein, uz kazein, odgovoran za alergije na proteine mlijeka koje se javljaju u velikom postotku djece hranjene $\mathrm{s}$ mliječnim zamjenama (uglavnom su one kravljeg podrijetla). Navedena alergija jedna je od najčešćih alergija u ljudi prouzročenih hranom, što je dovelo do brojnih istraživanja kobiljeg, kozjeg i devinog mlijeka kao alternative u slučaju hipersenzitivnih reakcija na kravlje mlijeko (Businco i sur., 2000., El-Agamy, 2006.). Za mlijeko sisavaca karakterističan je i $\boldsymbol{\alpha}$-laktalbumin, koji ima regulatornu ulogu u sintezi laktoze $u$ završnom koraku, kada se glukoza veže za galaktozu (Neville, 2009.).

Antimikrobna svojstva kobiljeg i humanog mlijeka uglavnom se temelje na prisustvu lizozima i, u manjoj mjeri laktoferina, koji prevladava $\mathrm{u}$ humanom mlijeku, a u kravljem ga gotovo niti nema. Imunoglobulini su najznačajniji obrambeni čimbenici $u$ kravljem su mlijeku, a u najvećoj su mjeri prisutni u kolostrumu. Laktoferin 
Tabela 2. Prikaz proteina sirutke $\left(\mathrm{g} \mathrm{kg}^{-1}\right)$ u kobiljem, humanom i kravljem mlijeku

\begin{tabular}{|l|c|c|c|}
\hline Protein & Kobila & Žena & Krava \\
\hline Ukupni proteini sirutke & 8,3 & 6,2 & 6,3 \\
\hline B-laktoglobulin & 2,55 & - & 3,2 \\
\hline a-laktalbumin & 2,37 & 2,5 & 1,2 \\
\hline Serumski albumin & 0,37 & 0,48 & 0,4 \\
\hline Imunoglobulini & 1,63 & 0,96 & 0,80 \\
\hline Laktoferin & 0,58 & 1,65 & 0,10 \\
\hline Lizozim & 0,87 & 0,34 & $126 \times 10^{-6}$ \\
\hline
\end{tabular}

Izvor: Uniacke-Lowe i sur. (2010.)

je multifunkcionalni glikoprotein koji veže željezo, strukturalno je vrlo sličan proteinu plazme transferinu, a osobito je zastupljen $\mathrm{u}$ kolostrumu, sudjeluje i u imunom odgovoru, a ima i antibakterijski učinak (Conneely, 2001.). Lizozim je enzim prisutan u mlijeku koji katalizira hidrolizu glikozidnih veza mukopolisaharidne bakterijske stanične stijenke, a u kravljem, ovčjem i kozjem mlijeku gotovo ga nema (Chiavari i sur., 2005.). Lizozim, zajedno $\mathrm{s}$ imunoglobulinima, laktoferinom i laktoperoksidazom, može u probavnom sustavu mladunčadi smanjiti pojavu gastrointestinalih infekcija (Businco i sur., 2000.). Salimei i sur. (2004.) dovode u vezu nisku bakterijsku kontaminaciju magarećeg i kobiljeg mlijeka s ovim enzimom. Imunoglobulini čine prirodnu obranu organizma od infekcije, a relativni odnosi imunoglobulina (IgG/ $\operatorname{IgA} / \operatorname{IgM}$ ) u mlijeku razlikuju se između vrsta samog mlijeka (Uniacke-Love i sur., 2010., Hurley i Theil, 2011.).

Kazeini iz mlijeka su primarni izvor aminokiselina, kalcija, fosfata i bioaktivnih peptida za mladunčad (Shekar i sur., 2006.). Biološka funkcija kazeina leži u sposobnosti formiranja makromolekularnih struktura kazeinskih micela koje prenose velike količine kalcija, neophodnog za razvoj mladunčadi, a uz minimalan rizik patološke kalcifikacije mliječne žlijezde. Kobilje mlijeko sadrži manje kazeina (približno 55 \% ukupnih proteina), slično kao humano mlijeko u kojem je postotak kazeina oko 40 \% (Sheng i Fang, 2009.) u odnosu na kravlje koje sadrži približno 80 \% kazeina (Uniacke-Lowe i sur., 2010.).

Glavne frakcije kazeina $u$ gotovo svim vrstama mlijeka su $\alpha_{\mathrm{s} 1} ; \alpha_{\mathrm{s} 2}-; \beta-; \gamma-\mathrm{i} \kappa-$ kazein. Sve frakcije nastaju produkcijom mliječne žlijezde, osim $\gamma$-kazeina, koji je rezultat transformacije sastojaka nastalih proteolizom $\beta$-kazeina, djelovanjem proteinaze mlijeka ili proteolitičkom aktivnosti bakterija (Tratnik, 1998.). U kobiljem su mlijeku frakcije $\alpha_{\mathrm{s}}$ i $\beta$ zastupljene $u$ gotovo jednakim omjerima,

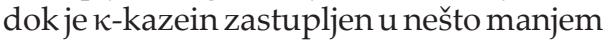
postotku (Ochirkhuyag i sur., 2000.) i pokazuje neke biokemijske sličnosti $\mathrm{s}$ bovinim i humanim $\kappa$ - kazeinom. Sastav kravljeg kazeina dobro je poznat; relativno je bogat $\mathrm{s} \alpha_{\mathrm{s} 1}$ kazeinom, koji je uzrok alergija u djece. Visok sadržaj kazeina u kravljem mlijeku prouzroči stvaranje čvrstog koaguluma u želucu, a i probava traje 3-5 sati. Iz kobiljeg i humanog mlijeka stvara se mekši precipitat čija probava u želucu traje kraće, oko 2 sata (Kalliala i sur., 1951.). Struktura oba kazeina i kravljeg i kobiljeg razlikuje se od onog iz humanog mlijeka u kojem uglavnom prevladava $\beta$-kazein. Ipak, kobilje se mlijeko smatra relativno 
bogato s $\beta$-kazeinom i može nadomjestiti potrebe djece.

Micele su složene nakupine po kojima se prepoznaje struktura kazeinskog kompleksa, a njihova struktura i veličina varira o vrsti. Micele iz kobiljeg mlijeka veće su od ostalih vrsta mlijeka. U kravljem i kobiljem mlijeku micele imaju spužvastu strukturu, dok im je u humanom mlijeku zbog kanala i kaverna struktura retikularna, pravilna i labava, a to utječe na osjetljivost prema pepsinu, jer je hidroliza kazeina uglavnom ovisna o velikoj količini $\beta$ - kazeina $u$ micelama. Razlike u sastavu proteina in toto (odnos kazeina i proteina sirutke) i različite micelarne strukture (raspodjela kazeina i veličina micela) određuju značajne razlike i svojstva grušanja mlijeka i posljedično tome probavljivost $\mathrm{i}$ iskoristivost hranjivih tvari iz mlijeka. Kobilje i humano mlijeko stvaraju nježne precipitate koji su fiziološki, jer su lakše probavljivi od koaguluma iz kravljeg mlijeka pogodniji za prehranu djece. Raspodjela kazeina u kobiljem mlijeku i usporedba $s$ humanim i kravljim mlijekom prikazana je u Tabeli 3.

\section{Mliječna mast i sastav masti u kobiljem mlijeku}

Budući da izravno utječu na ljudsko zdravlje, prije svega na pojavu krvožilnih bolesti u dijetetici se mnogo govori o unosu masnoća. Kvalitetna i zdrava prehrana ne podrazumijeva samo unos smanjene količine masti, već i optimalan omjer zasićenih i nezasićenih masnih kiselina (Orlandi i sur., 2003.). Vrlo je bitna i kvaliteta unesenih masti i masnih kiselina, pogotovo tijekom rasta mladog organizma, jer se osim na razvoj, odražavaju dugoročno i na zdravstveno stanje organizma.

Osim što su neophodan izvor energije, nezamjenjivi su u metaboličkim i strukturalnim aktivnostima. Primjerice, lipidi su strukturalni tkivni sastojci i neophodni su za sintezu stanične membrane. Mliječna mast $u$ svih sisavaca sadrži zasićene masne kiseline građene od lanaca različite duljine i manje količine nezasićenih masnih kiselina (Gantner i sur., 2015.). S aspekta nutritivne vrijednosti, veliko se značenje pridaje ulozi polinezasićenih masnih kiselina, nužnim za velik broj tjelesnih funkcija, ponajprije $u$ imunološkom, kardiovaskularnom i živčanom sustavu. Najznačajnije kategorije s obzirom na prisustvo dvostrukih veza i cis konfiguraciju su n-6 i n-3. Masne kiseline su i bitni prekursori eikozanoida prostaglandina, prostaciklina, tromboksana i leukotrina, koji imaju snažnu autokrinu ili parakrinu regulaciju bitnih funkcija poput agregacije trombocita, upalne reakcije, vazokonstrikcije i vazodilatacije (Uauy i Hoffman, 2000.). U kobiljem mlijeku potvrđena je visoka koncentracija povoljnih masnih kislina, kao i niske vrijednosti aterogenih i trombogenih

Tabela 3. Prikaz i usporedba kazeinskih frakcija u kobiljem, humanom i kravljem mlijeku

\begin{tabular}{|l|c|c|c|}
\hline & Kobila & Žena & Krava \\
\hline Ukupni kazein $\left(\mathrm{g} \mathrm{kg}^{-1}\right)$ & 10,7 & 3,7 & 25,1 \\
\hline $\mathrm{a}_{\mathrm{s}}$ - kazein \% & 46,65 & 11,75 & 48,46 \\
\hline$\beta-$ kazein \% & 45,64 & 64,75 & 35,77 \\
\hline K- kazein \% & 7,71 & 23,50 & 12,69 \\
\hline Veličina micela $(\mathrm{nm})$ & 255 & 64 & 182 \\
\hline
\end{tabular}

Izvor: Sheng i Fang (2009.) izražena je srednja vrijednost pronađena u literaturi 
Tabela 4. Raspon i srednja vrijednost mliječne masti u mlijeku različitih vrsta

\begin{tabular}{|c|c|c|c|}
\hline & Raspon & Srednja vrijednost & Izvor \\
\hline \multirow{2}{*}{ Kobila } & 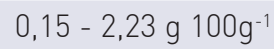 & $0,72 \pm 0,82$ & Smiddy i sur. 2012. \\
\hline & & 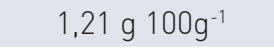 & Malacarne i sur. 2002 \\
\hline Krava & 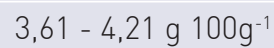 & $3,89 \pm 0,19$ & Smiddy i sur. 2012. \\
\hline Žena & & 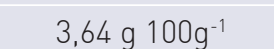 & Malacarne i sur. 2002 \\
\hline
\end{tabular}

indeksa, važnih u prevenciji krvožilnih bolesti (Czyzak-Runowska i sur., 2021.).

Zbog nepostojanja potrebnih enzima, ljudi i drugi sisavci ne mogu sintetizirati linolnu (LA) i $\alpha$-linolensku kiselinu (ALA), već ih moraju unositi u organizam putem hrane, što i uvjetuje njihovu esencijalnost (Simopoulus, 1999.). Smatra se da je količina zasićenih masnih kiselina u kravljem mlijeku zastupljena s oko 70 $\%$ od ukupne količine, mononezasićenih ima oko $27 \%$, a di- i trinezasićenih ima samo oko $3 \%$. Od zasićenih masnih kiselina najviše ima palmitinske, a od nezasićenih oleinske. Esencijalnih masnih kiselina (linolna, linolenska i arahidonska) u mliječnoj masti ima manje nego u biljnim mastima (Tratnik, 1998.).

Kobilje mlijeko ima nizak udio mliječne masti, a istodobno sadrži visok udio višestruko nezasićenih masnih kiselina, što ukazuje na poželjniji dijetetski sastav nego u kravljem mlijeku (Csapo i sur., 1995.). Razlog povoljnijeg omjera nezasićenih i zasićenih masnih kiselina $u$ kobiljem mlijeku je odsutnost hidrogenacije masnih kiselina $u$ probavnom traktu prije apsorpcije, što se događa u preživača (Hoffman i sur., 1998.), kao i znatne količine trave bogate $\alpha$-linolenskom kiselinom u prehrani konja. Hrana drugih monogastričnih vrsta, koje nisu herbivori, tom je masnom kiselinom siromašna (Doreau i Martuzzi, 2006.). Više istraživanja ukazuje da unos linolenske kiseline prehranom može biti koristan kod liječenja nekih atopijskih dermatitisa $u$ djece (Vincenzetti i sur., 2008.). Mliječna se mast spominje $u$ literaturi i kao važan izvor potencijalnih antikarcinogena iz konjugirane linolne kiseline (CLA). CLA najviše ima u mlijeku preživača, dok se u kobiljem mlijeku nalazi u puno manjim količinama, jer mikroorganizmi cekuma ne doprinose povećanju njezine koncentracije u mlijeku (Jahreis i sur., 1999.).

Mliječna je mast pod utjecajem više čimbenika kao što su: stadij laktacije, prehrana, vrsta životinje, stadij mužnje tijekom kojeg je uzet uzorak, vrijeme mužnje, kao i vrijeme između dvije mužnje (Smiddy i sur., 2012.). Sastav mlijeka varira čak i tijekom jedne mužnje, a najveće promjene zabilježene su upravo u količini mliječne masti, tako da je na kraju mužnje može biti 10 do 20 puta više, nego na početku (Salamon i sur., 2009.). Broj ždrijebljenja i starost kobila ne utječu značajno na sadržaj masti u mlijeku (Pikul i sur., 2008.). Kao što je prikazano u Tabeli 4., količina masti u kobiljem mlijeku vrlo je mala u usporedbi s kravljim i humanim mlijekom.

U kobiljem je mlijeku mast uobličena $\mathrm{u}$ emulgiranim globulima veličine 2-3 um. Globuli su obavijeni s tri membrane; unutrašnjom proteinskom, središnjom fosfolipidnom i vanjskom glikoproteinskom velike molekularne težine (Malacarne i sur., 2002.). Upravo ti glikoproteini imaju značajnu ulogu u biomodulacijskim svojstvima mlijeka i u konačnici određuju kvalitetu i hranjivost mlijeka (O'Riordan i sur., 2014.). Na površini glikoproteina nalazi se razgranata struktura oligosaharida, slična onoj na masnim globulima $u$ 
Tabela 5. Sastav lipida u kobiljem mlijeku i usporedba s humanim i kravljim mlijekom

\begin{tabular}{|l|c|c|c|}
\hline Lipidi & Kobila & Žena & Krava \\
\hline Mast (g kg-1) & 12,1 & 36,4 & 36,1 \\
\hline Trigliceridi (\%) & 81,1 & 98,0 & 97,0 \\
\hline Fosfolipidi (\%) & 5,0 & 1,3 & 1,5 \\
\hline Nesaponificirajuće (\%) & 4,5 & 0,7 & 1,5 \\
\hline Slobodne masne kiseline (nm) & 9,4 & u tragovima & u tragovima \\
\hline
\end{tabular}

Izvor: Malacarne i sur., 2002.

humanom mlijeku. Za usporedbu, u humanom mlijeku prosječni dijametar masnih globula iznosi 3- $5 \mu \mathrm{m}$.

Sastav lipida u kobiljem mlijeku prikazan je u Tabeli 5. Od ukupne količine lipida, trigliceridi čine oko 80 $\%$ triglicerida, a to je manje $\mathrm{u}$ odnosu na humano i kravlje mlijeko. Broj ugljikovih atoma $\mathrm{u}$ di- $\mathrm{i}$ tri-gliceridima je različit, ovisno o vrsti, a sama struktura triglicerida utječe na djelotvornost lipolitičkih enzima i apsorpciju masti. Najvažnijim fosfolipidima $u$ mlijeku smatraju se glicerofosfolipidi i sfingolipidi, a oni se nalaze na membrani globula mliječne masti. Postoje značajni dokazi da imaju blagotvorne učinke na zdravlje, kao što su regulacija upalnih reakcija te kemopreventivna i kemoterapijska aktivnost, a utječu i na apsorpciju kolesterola (Contarini i Povolo, 2013.). U kobiljem je mlijeku utvrđena niža količina kolesterola $u$ odnosu na humano i kravlje, u kojima su utvrđene podjednake vrijednosti (Gantner i sur., 2015., Navrátilová i sur., 2018.).

Uspoređujući sadržaj masnih kiselina u kobiljem s humanim i kravljim mlijekom, prema velikom broju autora, najznačajnije su razlike $u$ količini zasićenih, jednostruko i višestruko nezasićenih masnih kiselina. Kao i u humanom, u kobiljem je mlijeku niži omjer zasićenih masnih kiselina s manjim i većim brojem ugljikovih atoma $\left(\mathrm{C}_{4: 0}\right.$; $\left.\mathrm{C}_{6: 0} ; \mathrm{C}_{16: 0} ; \mathrm{C}_{18: 0}\right)$. U cijelosti postotak nezasićenih masnih kiselina $\mathrm{u}$ kobiljem i humanom mlijeku je podjednak i veći nego u kravljem mlijeku. Ova činjenica povećava prehrambenu vrijednost kobiljeg mlijeka. Slobodne masne kiseline u kobiljem mlijeku nalaze se u značajnim količinama, dok su u druge dvije vrste mlijeka prisutne tek $\mathrm{u}$ tragovima.

Sastav masti u kobiljem mlijeku osobit je i razlikuje se od ostalih vrsta mlijeka zbog visokog sadržaja esencijalnih masnih kiselina, linolne i posebno, $\alpha$-linolenske, koje organizam nije $u$ mogućnosti sintetizirati sam, a imaju značajne biološke funkcije.

\section{Probavljivost kobiljeg mlijeka}

Mlijeko se općenito smatra lako probavljivom namirnicom, a probavni sustav sisavaca pomoću mehanizma stvaranja koaguluma u želucu, usporava pasažu mlijeka i degradaciju proteina. Tvrdoća koaguluma ovisi o količini kazeina u mlijeku. Humano i mlijeko ekvida, u kojem ima manje od $60 \%$ kazeina, stvara mekani ugrušak, za razliku od kravljeg mlijeka, koje se duže zadržava u želucu. Zbog sličnog profila proteina u kobiljem i humanom mlijeku, smatra se da je kobilje mlijeko prikladnije u prehrani ljudi (Uniacke-Lowe, 2011.). Eksperimentima provedenim in vitro, Kalliala i sur. (1951.) naglasili su sličnost kobiljeg i humanog mlijeka i izvijestili o trajanju probave ugruška mlijeka. Probava kravljeg mlijeka trajala je 3 
do 5 sati, a stvoreni koagulum bio je kompaktan, za razliku od probave humanog mlijeka, koja traje 2 do 2,5 sata i stvaraju se fine, rastresite nakupine.

Koncentracije masti, proteina i laktoze u kobiljem mlijeku, prema različitim autorima, prikazane su u Tabeli 6. Uočljivo je da kobilje mlijeko sadrži značajno više laktoze od kravljeg mlijeka. Ukoliko se konzumira sirovo, svježe kobilje mlijeko može imati laksativni učinak. Kumis je fermentirano kobilje mlijeko pripremljeno s bakterijama mliječno kiselog vrenja, koje razgrađuju laktozu na mliječnu kiselinu, etanol i ugljični dioksid, što ovaj proizvod čini prihvatljivim i za laktoza intolerantne osobe. Kumis originalno potječe od nomadskih naroda središnje Azije. Tradicionalno pripremljen napitak dobiva se miješanjem fermentiranog i svježeg kobiljeg mlijeka. Nedavnim istraživanjima dokazano je da se fermentacijom kobiljeg mlijeka količina nekih vitamina topivih u vodi značajno ne mijenja, dok se razina određenih aminokiselina povećava, čime se potvrđuje prisustvo važnih komponenti $\mathrm{u}$ sirovom i fermentiranom kobiljem mlijeku (Teichert i sur., 2021.).

\section{Utjecaj laktacije na sastav mlijeka}

U prvim satima života ždrjebeta unos kolostruma je od presudne važnosti. Trajanje kolostralnog razdoblja može, prema različitim autorima, trajati od jednog do tjedan dana. Objavljeni rezultati o sastavu kolostruma su varijabilni, što je objašnjeno uporabom različitih metoda i činjenicom da se unutar prvih 12 sati nakon ždrijebljenja događaju najznačajnije promjene $u$ sastavu kolostruma. Najveće promjene primjećene su $\mathrm{u}$ količini bjelančevina, kojih je u kolostrumu znatno više nego $\mathrm{u}$ mlijeku te $\mathrm{u}$ količini mliječne masti (Ernoić, 1998., Barreto i sur., 2020.). Prema Martuzzi i sur. (2004.), kobilje je mlijeko na kraju laktacije siromašnije od mlijeka s početka laktacije u svim organskim sastojcima, osim laktoze, kao i u svim mineralnim komponentama, osim natrija, a promjene nisu statistički značajne.

\section{Zaključak}

Uspoređujući ga s humanim i kravljim mlijekom, kobilje mlijeko ima nižu energetsku vrijednost i niže vrijednosti masti. Sadržaj proteina $u$ kobiljem mlijeku sličan je onom u humanom. Sadržaj proteina sirutke $u$ kobiljem mlijeku čini ovo mlijeko pogodnijem od kravljeg za prehranu ljudi. Kazein $\mathrm{u}$ kobiljem mlijeku sastavljen je od približno jednakih dijelova $\beta$ - i $\alpha s-$ kazeina. U humanom mlijeku prevladava $\beta$ - kazein, dok je u kravljem najzastupljeniji $\alpha s-$ kazein, kojeg se smatra uzrokom alergijskih reakcija kod dojenčadi. Kobilje i humano mlijeko

Tabela 6. Koncentracije komponenti kobiljeg mlijeka

\begin{tabular}{|l|c|c|c|}
\hline Autor, godina $(\mathbf{g} / \mathbf{1 0 0 g}$ ili $\%)$ & Mast & Proteini & Laktoza \\
\hline Barreto i sur., 2020. & $0,73 \pm 0,45$ & $1,68 \pm 0,26$ & $6,62 \pm 0,3$ \\
\hline Čagalj i sur., 2014. & 1,23 & 1,76 & 6,26 \\
\hline Končurat i sur., 2019. & 0,96 & 1,95 & 6,48 \\
\hline Marconi i Panfili, 1998. & 1,8 & 2,5 & 6,1 \\
\hline Martuzzi i sur. 2004. & $1,17-0,76$ & $2,31-1,68$ & $6,61-6,70$ \\
\hline Summer i sur., 2000. & $1,04-0,44$ & $2,23-1,63$ & $6,65-6,88$ \\
\hline
\end{tabular}


formiraju finiji, nježniji precipitat, koji je mnogo lakše probavljiv od koaguluma u kravljem mlijeku. Vanjska membrana masnih globula, kao i raspodjela di- i triglicerida iz kobiljeg i humanog mlijeka su slične. Postotak nezasićenih masnih kiselina u kobiljem i humanom mlijeku veći je nego u kravljem mlijeku, a najveći dio otpada na polinezasićene masne kiseline sa srednjim i većim brojem ugljikovih atoma (PUFA).

\section{Literatura}

1. BARRETO, I. L., S. A. URBANO, C. A. A. OLIVEIRA, C. S. MACÊDO, L. H. F. BORBA, BRUNA M. E. CHAGS and A. H. N. RANGEL (2020): Chemical composition and lipid profile of mare colostrum and milk of the quarter horse breed. PLoS ONE 15 (9), https://doi.org/10.1371/ journal.pone.0238921.

2. BREZOVEČKI, A., M. ČAGALJ, N. ANTUNAC, N. MIKULEC and D. BENDELJA LJOLJIĆ (2014): Proizvodnja, sastav i svojstva kobiljeg mlijeka, Mljekarstvo 64, 217-227.

3. BUSINCO, L., P. G. GIAMPIETRO, P. LUCENTI, F. LUCARONI, C. PINI, G. DI FELICE, P. IACOVACCI, C. CURADI and M. ORLANDI (2000): Allergenicity of mare's milk in children with cow's milk allergy. J. Allergy Clin. Immunol. 105, 1031-1034.

4. CAROPRESE, M., M. ALBENZIO, R. MARINO, A. MUSCIO, T. ZEZZA and A. SEVI (2007): Behavior, milk yield and milk composition of machine and hand-milked Murgese mares. J. Dairy Sci. 90, 27732777.

5. CASEY, C. E. (1989): The nutritive abd metabolic advantages of homologous milk. Proc. Nutr. Soc. $48,271-281$.

6. CHIAVARI, C., F. COLORETTI, M. NANNI, E. SORRENTINO and L. GRAZIA (2005): Use of donkey 's milk for a fermented beverage with lactobacilli. Lait 85, 481-490.

7. CSAPO, J., J. STEFLER, T. G. MARTIN, S. MAKRAY and ZS. CSAPO-KISS (1995): Composition of mare's colostrum and milk I. Fat content, fatty acid composition and vitamin contents. Int. Dairy J. 5, 393-402.

8. CSAPO-KISS, ZS., J. STEFLER, T. G. MARTIN, S. MAKRAY and J. CSAPO (1995): Composition of mare's colostrum and milk II. Protein content, amino acid composition and contents of macro- and micro elements. Int. Dairy J. 5, 403-415.

9. CONNEELY, O. (2001): Antiinflammatory activities of lactoferrin. J. Am. Coll. Nutr. 20, 389S-395S.

10. CONTARINI, G. and M. POVOLO (2013): Phospholipids in Milk Fat: Composition, Biological and Technological Significance, and Analytical Strategies. Int. J. Mol. Sci. 14, 2808-2831.

11. CZYZAK-RUNOWSKA, G., J. A. WÓJTOWSKI, R. DANKÓW and D. STANISŁAWSKI (2021): Mare's Milk from a Small Polish Specialized Farm-Basic Chemical Composition, Fatty Acid Profile, and Healthy Lipid Indices, Animals 11, 1590. https:// doi.org/10.3390/ani11061590

12. ČAGALJ, M., A. BREZOVAČKI, N. MIKULEC and N. ANTUNAC (2014): Composition and properties of mare's milk of Croatian Coldblood horse breed. Mljekarstvo 64, 3-11.

13. EL-AGAMY, E. I. (2006): The challenge of cow milk protein allergy. Small Ruminant Res. 68, 64-72.

14. DOREAU, M. and F. MARTUZZI (2006): Fat content and composition of mare's milk. In: Nutrition and feeding of the broodmare, EAAP Public. 120, 77-87.

15. ELLINGER, S., K. P. LINSCHEID, S. JAHNECKE, R. GOERLICH and H. ENBERGS (2002): The Effect of Mare's Milk Consumption on Functional Elements of Phagocytosis of Human Neutrophil Granulocytes From Healthy Volunteers. Food Agr. Immunol. 14, 191-200.

16. ERNOIĆ, M. (1998): Proizvodnja kobiljeg mlijeka kao alternativa iskorištavanja konja u Hrvatskoj. Sveučilište u Zagrebu, Agronomski fakultet. Magistarski rad. Rukopis, 91 str.

17. FORMAGGIONI, P., M. MALACARNE, F. MARTUZZI, A. SUMMER and P. MARIANI (2003): Casein number variability of mare milk from Haflinger and Italian Saddle horse breeds. Ann. Fac. Medic.Vet., Univ. Parma 13, 175-179.

18. FOX, P. F. (2001): Milk proteins as food ingredients. Int. J. Dairy Technol. 54, 41-55.

19. GANTNER, V., P. MIJIĆ, M. BABAN, Z. ŠKRTIĆ and A. TURALIJA (2015): The overall and fat composition of milk of various species. Mljekarstvo 65, 223-231.

20. HOFFMAN, R. M., D. S. KRONFELD, J. H. HERBEIN, W. S. SWECKER, W. L. COOPER and P. A. HARRIS (1998): Dietary carbohydrates and fat influence milk composition and fatty acid profile of mares milk. J. Nutr. 128, 2708S-2711S.

21. HURLEY, W. L. and P. K. THEIL (2011) Perspectives on immunoglobulins in colostrum and milk. Nutrients 3, 442-474.

22. IVANKOVIĆ, A., J. RAMLJAK, I. ŠTULINA, N. ANTUNAC, I. BAŠIĆ, N. KELAVA and M. KONJAČIĆ (2009): Characteristics of the lactation, chemical composition and milk hygiene quality of the Littoral- Dinaric ass. Mljekarstvo 59, 107-113.

23. JAHREIS, G., J. FRITSCHE, P. MÖCKEL, F. SCHÖNE, U. MÖLLER and H. STEINHART (1999): The potential anticarcinogenic conjugated linoleic acid, cis-9,tranS-11 C18:2, in milk of different species: cow, goat, ewe, sow, mare, woman. Nutr. Res. 19, 1541-1549.

24. KALLIALA, H., E. SELESTE and N. HALLMAN (1951): On the use of mare's milk in infant feeding. Acta paediatr. 40, 94-117. 
25. KONČURAT, A., L. KOZAČINSKI, N. BILANDŽIĆ, Ž. CVRTILA, T. SUKALIĆ, M. SEDAK and M. BENIĆ (2019): Microbiological quality of mare's milk and trends in chemical composition by comparison of different analytical methods. Mljekarstvo 69, 138-146.

26. MALACARNE, M., F. MARTUZZI, A. SUMMER and P. MARIANI (2002): Protein and fat composition of mare's milk: some nutritional remarks with reference to human and cow's milk. Int. Dairy J. 12, 869-877.

27. MARCONI, E. and G. PANFILI (1998): Chemical composition and nutritional properties of commercial products of mare milk powder. J. Food Compos. Anal. 11, 178-187.

28. MARTIN, R. G., N. P. MCMENIMAN and K F. DOWSET (1992): Milk and waters intakes of foals sucking grazing mares. Equine Vet. J. 24, 295-299.

29. MARTUZZI, F., A. L. CATALANO, A. SUMMER and P. MARIANI (1997): Calcium, phosphorus and magnesium in the milk of nursing mares from Italian Saddle horse breed and their variations during lactation. Ann. Fac. Med. Vet., Univ. Parma 17, 205-212.

30. MARTUZZI, F., A. SUMMER, P. FORMAGGIONI and P. MARIANI (2004): Milk of Italian Saddle and Haflinger nursing mares: physicochemical characteristics, nitrogen composition and mineral elements at the end of lactation. Ital. J. Anim. Sci. 3, 293-299.

31. NAVRÁTILOVÁ, P., J. POSPÍŠIL, I. BORKOVCOVÁ, L. KANIOVÁ, S. DLUHOŠOVÁ and S. HORÁKOVÁ (2018): Content of nutritionally important components in mare milk fat. Mljekarstvo 68, 282-294.

32. NEVILLE, M. C. (2009): Introduction: alphalactalbumin, a multifunctional protein that specifies lactose synthesis in the Golgi. J. Mammary Gland Biol. Neoplasia 14, 211-212.

33. OCHIRKHUYAG, B., J. M. CHOBERT, M DALGALARRONDO and T. HAERTLE (2000): Characterization of mare caseins. Identification of $\alpha_{\mathrm{s} 1}-\mathrm{i} \alpha_{\mathrm{s} 2}$ - kazeina. Lait, 80, 223-235.

34. O'RIORDAN, N., M. KANE, L. JOSHI and R. M. HICKEY (2014): Structural and functional characteristics of bovine milk protein glycosylation. Glycobiology 24, 220-236.

35. ORLANDI, M., J. GORACCI and M. C. CURADI (2003): Fat composition of mare's milk with reference to human nutrition. www.biblio.vet. unipi.it/annali2003/97.pdf, 97- 105.

36. PIESZKA, M., J. LUSZCZYNSKI and A. SZEPTALIN (2011): Comparison of mare's milk composition of different breeds. Nauka Przyr. Tech. 5 (6) \#112.

37. PIKUL, J., J. WOJTOWSKI, R. DANKOW, B. KUCZYNSKA and J. LOJEK (2008): Fat content and fatty acids profile of colostrum and milk of primitive Konik horses (Equus caballus gmelini Ant.) during six months of lactation. J. Dairy Res. $75,302-309$
38. POTOČNIK, K., V. GANTNER, K. KUTEROVAC and A.CIVIDINI (2011): Mare's milk: composition and protein fraction in comparison with different milk species, Mljekarstvo 31, 107-113.

39. SALAMON, R. V., S. Z. SALAMON, Z. S. CSAPOKISS and J. CSAPO (2009): Composition of mare's colostrum and milk I. Fat content, fatty acid composition and vitamin contents. Acta Univ. Sapientiae, Alimentaria 2, 119-131.

40. SALIMEI, E., F. FANTUZ, R. COPPOLA, B. CHIOFALO, P. POLIDORI and G. VARISCO (2004): Compostotion and characteristics of ass's milk. Anim. Res. 53, 67-78.

41. SHENG, Q. and X. FANG (2009): Bioactive components in Mare milk. Chapter 7 in Bioactive components in milk and dairy products. Young W. Park, Wiley-Blackwell, pp. 195-213.

42. SHEKAR, P. C., S. GOEL, S. D. S. RANI, D. P. SARATHI, J. L. ALEX, S. SINGH and S. KUMAR (2006): $\kappa$-Casein - deficient mice fail to lactate. Proc. Natl. Acad. Sci. USA 103, 8000-8005.

43. SIMOPOULUS, A. P. (1999): Essential fatty acids in health and chronic disease. Am. J. Clin. Nutr. 70 (suppl), 560S-569S.

44. SMIDDY, M. A., T. HUPPERTZ and S. M. VANRUTH (2012): Triacylglycerol and melting profiles of milk fat from several species. Int. Dairy J. 24, 64-69.

45. STARBUCK, G. R. (2006): Physiology of lactation in the mare. In: Nutrition and feeding of the broodmare, EAAP Public. 120, 49-55.

46. SUMMER, A., P. FORMAGGIONI, S. FILIPPINI, F. MARTUZZI, A. L. CATALANO and P. MARIANI (2000): Physico- chemical properties and energy value of Haflinger nursing mare milk during 6 lactation months. http://old.unipr.it/arpa/facvet/ annali/2000/summer/summer.htm

47. TEICHERT, J., D. CAIS-SOKOLIŃSKA, P. BIELSKA, R. DANKÓW, S. CHUDY, L. K. KACZYŃSKI and J. BIEGALSKI (2021): Milk fermentation affects amino acid and fatty acid profile of mare milk from Polish Coldblood mares. Int. Dairy J. 121, https://doi. org/10.1016/j.idairyj.2021.105137

48. TRATNIK, LJ. (1998): Mlijeko - tehnologija, biokemija i mikrobiologija. Hrvatska mljekarska udruga, Zagreb, 1998.

49. UAUY, R. and D. R. HOFFMAN (2000): Essential fat requirements of preterm infants. Am J. Clin. Nutr. 71 (suppl), 245S-250S

50. UNIACKE-LOWE, T., T. HUPPERTZ and P. F. FOX (2010): Equine milk proteins: Chemistry, structure and nutritional significance. Int. Dairy J. 20, 609-629.

51. UNIACKE-LOWE, T. (2011): Studies on equine milk and comparative studies on equine and bovine systems. PhD Thesis, University Collede Cork.

52. VINCENZETTI, S., P. POLIDORI, P. MARIANI, N. CAMMERTONI, F. FANTUZ and A. VITA (2008): Donkey's milk protein fractions charecterization. Food Chem. 106, 640-649. 


\section{Nutritional specificity of protein and fat in mare milk compared to human and cow milk}

Ana KONČURAT, DVM, PhD, Scientific Associate, Croatian Veterinary Institute, Regional Department Križevci, Croatia; Lidija KOZAČINSKI, DVM, PhD, Full Professor, Faculty of Veterinary Medicine University of Zagreb Croatia; Nina BILANDŽIĆ, Grad. Biotechnology Eng., $\mathrm{PhD}$, Scientific Advisore in Tenure, Croatian Veterinary Institute, Zagreb, Croatia; Tomislav SUKALIĆ, DVM, PhD, Postdoctorand, Željko CVETNIĆ, DVM, PhD, Academician, Croatian Veterinary Institute, Regional Department Križevci, Croatia

The composition of mare, human and cow milk differs significantly depending on the genetic, physiological and nutritional factors, and environmental conditions. Compared to human and cow milk, mare milk has lower energy and fat values, while the protein content of mare milk is similar to human milk. The content of whey protein and casein in mare milk makes it more suitable than cow milk for human consumption. Mare and human milk form a precipitate, which is much easier to digest than cow milk coagulum, and the outer membrane of fat globules and the distribution of di- and triglycerides from mare and human milk are also similar. The percentage of unsaturated fatty acids in mare and human milk is higher than in cow milk, most of which are polyunsaturated with a moderate to higher number of carbon atoms. Due to its specific chemical and nutritional properties, mare milk is in the focus of interest as a functional and healthy food.

Key words: mare milk; proteins; fats; comparison 